\title{
Elite Delights: The Structure of Art Gallery Networks in India
}

\section{Olivier Roueff}

\section{OpenEdition}

\section{Journals}

\section{Electronic version}

URL: http://journals.openedition.org/samaj/4271

DOI: 10.4000/samaj.4271

ISSN: $1960-6060$

\section{Publisher}

Association pour la recherche sur l'Asie du Sud (ARAS)

Electronic reference

Olivier Roueff, «Elite Delights: The Structure of Art Gallery Networks in India », South Asia

Multidisciplinary Academic Journal [Online], 15 | 2017, Online since 16 January 2017, connection on 01 May 2019. URL : http://journals.openedition.org/samaj/4271 ; DOI : 10.4000/samaj.4271

This text was automatically generated on 1 May 2019.

\section{(c) $($ i) $(9)$}

This work is licensed under a Creative Commons Attribution-NonCommercial-NoDerivatives 4.0 International License. 


\title{
Elite Delights: The Structure of Art Gallery Networks in India
}

\author{
Olivier Roueff
}

1 The transformations of contemporary art worlds around the globe are quite well known. ${ }^{1}$ The valorization of innovation over the classical canon became a norm in Europe at the end of the nineteenth century, when "modernist" artists began to rely on art dealers and art critics in order to differentiate their practice from handicrafts and functional purposes, and to pursue "art for art's sake" against religious, political, and economic patronages. The "dealer-critic system" (Moulin 1967) evolved after World War II in Western areas, mainly through the rise of art museums and their curators (Heinich and Pollak 1989; Jeanpierre and Sofio 2015), whose authority played a key role in the economic valorization of the new "abstract" styles launched by avant-garde artists and their galleries (Crane 1987; Verlaine 2013). Since the 1970s, the game has become more complex with a lot of new players, both geographically (through globalization, still segmented between "East" and "West" (Crane 2016)) and functionally, with mainly economic actors: international fairs (Yogev and Krund 2012; Roux 2006); "big" collectors and auction firms (Moureau and Sagot-Duvauroux 2012; Quemin 2013); web dealers and web hierarchized databases (Moulin 1992; Moulin 2000)-all of whom impose more and more market logics and values (Borja and Sofio 2009).

But if galleries are less central than before, they are still at the core of the value process (Peterson 1997; Jyrämä and Äyväri 2010), especially for peripheral artists (Karttunen 2008). As gatekeepers (Hirsch 1972), they select aspiring artists (Finney 1993), shape demand through their clientele, and some even redefine their role to become art producers (gathering funds and coalitions around artistic projects). As such, galleries illustrate the ideal type of cultural intermediaries and their structural dilemmas: translating artistic value into economic price and vice versa; matching consumers' tastes and artists' innovations; combining artists' interests and their own interests as entrepreneurs (Lizé, Naudier and Roueff 2011; Jeanpierre and Roueff 2014). In addition, art galleries are one of the main providers of symbolic goods for cultural elites, who dictate taste and lifestyle aspirations to the social groups that access cultural and 
economic capitals (Bourdieu 1979). This social role of art galleries is becoming increasingly true throughout the world with the globalization of art markets (Velthuis and Baia Curioni 2015). Their products are expensive and esoteric, and their buyers and collectors, as a ruling minority among upper classes, define aesthetic standards for their social group as well as for the broader middle classes (Jaffrelot and Veer 2008). Investigating art galleries and their aesthetic trends may thus offer some insight into shifting cultural standards among elites.

Within the body of existing work on contemporary art worlds, India has not yet been subject to much investigation. Important studies do exist, as shown above, but a systematic empirical inquiry into the Indian art world as a whole has yet to be made. The present article offers a step in that direction, through the statistical analysis of 101 Indian modern and contemporary visual art galleries and the 4,249 artists they present in their catalogs. Does the way galleries share artists reveal specific characteristics about the Indian art world? Is the usual opposition between "commercial" and "artistic" galleries relevant for contemporary India? What are the roles of auctions and international fairs? Do Indian galleries prefer to represent artists, or to store and exhibit their works? What insights do their strategies and hierarchies offer about the cultural standards of the Indian elite? In the first section, I will summarize the available literature about the Indian art world. Then data and methodology will be presented, along with the first results from bivariate analyses. The last section will offer a typology of Indian art galleries based on a network analysis: galleries are considered bonded when they share the same artist(s); a blockmodeling algorithm then calculates the best clusters of similar positions among this distribution of shared artists. ${ }^{2}$ The conclusion will then offer an interpretation of the cultural standards of Indian elites that can be derived from this analysis of visual art galleries.

\section{What is known about the Indian art world?}

4 A set of characteristics of the Indian art world can be gleaned from the few dedicated studies that have been done. ${ }^{3}$ First, galleries became major players only after Independence. But the market had already developed under colonial rule, mainly due to polycentric patronage structures. During the nineteenth century, with the creation of dedicated schools of art separate from handicraft (Calcutta, Bombay, and Madras in 1854) and of independent artist societies, artists began to free themselves from royal patronage and the demands of the colonial elites by moving from client to client. The most prominent artists circulated in foreign capitals (mainly London), which helped to connect Indian cultural circles with the aesthetic currents of Western modernism. Independence transformed the market by quickly reducing royal patronage in favor of large industrialists, and by promoting the creation of private galleries. However, public institutions of independent India (museums and universities) did not invest much in twentieth-century arts and never became canonization authorities to the extent that they did in other countries. Cultural nation-building was more focused on heritage museums than on the promotion of living artists enlisted in the struggle for Independence. Arts and crafts of the past were interpreted as evidence of continuities beyond the caesura of colonization, and the issue of promoting India as a modern society appeared to be a mere economic matter (Kapur 2000; Mitter 2007; Sinha 2009). 
5 Nevertheless, a crucial point is rarely stressed: the Indian state actually plays a significant role in artist recognition-through art departments in public or approved universities, some of which are among the most renowned, ${ }^{4}$ and via the national and local academies (Lalit Kala Akademi) and their training centers, workshops, group exhibitions, awards, and scholarships. A look at the curricula of hundreds of artists selected for exhibitions or dictionaries quickly reveals that very few do not include at least one Akademi credential. Private foundations, providing orders, grants, and residencies, were for their part undeveloped until the 2010s. ${ }^{5}$

6 Since the 1990s, the market of informal sales, galleries, and auctions has formed the core of the Indian art world. By informal I mean sales that are not mediated by a gallery or another commercial organization; they involve a buyer and a seller only, who usually already know each other's names (they are part of a "milieu," an interpersonal network), or sometimes an interpersonal intermediary (a collector, an acquaintance for whom the sale is an occasional act). Thus, the share of informal sales is impossible to assess. It is probably less important in terms of business volume than in terms of coalitions of actors at the top of the market, and in terms of collective ideology. Indeed, it is often exaggerated by insiders. It helps minimize the influence of the commercial logic inherent to capitalist enterprise, as if gallery meant "purely economic" and informal meant "friendly and disinterested." Above all, the phenomenon of informal sales draws a symbolic boundary between common people, who access works and artists through public places only (open galleries, museums, etc.), and the insiders, who are informed and integrated within interpersonal networks of cultural elites (Sooudi 2015; Sooudi 2012). Thus, regulars from the art world who frequent gallery openings and public auctions like to state that "real" value is built far from these semi-private but still much too public events. ${ }^{6}$ Galleries reflect this symbolic boundary by combining formal publicity and private informality in various ways. Some are accessible through appointment only. Most combine public exhibitions with invitational openings and private, "friendly" parties. Others develop formalized consulting or training for collectors, promising them visits to artists' studios and private collections. There is an emerging market of consulting agencies for novice collectors attracted by the hope of inside access. Few art professionals disdain such services. In the biographies of critics, curators, gallery owners, academics, patrons, and so forth, the words "art consultancy" appear frequently. There is also an editorial market, with the proliferation of "introductions," "dictionaries," "top 10 or 100" of Indian arts.

7 Another structural feature of the Indian art world is the increasing role of its auction market. Nothing better illustrates its rise than the advent of "Indian modern art," which has become a decisive aesthetic category. Khaire and Wadhwani (2010) showed that it did not exist in the 1980s. Galleries then managed to sell twentieth-century artists, especially to non-resident Indians, but it was still alongside antiques and traditional arts under the label of "Indian and Southeast Asian Art." In the early 1990s, art historians and critics reconceptualized twentieth-century Indian art as "modernist," claiming that its previous qualifications as "provincial" or "derivative" (of Western art) fell within a narrow ethnocentric vision of artistic modernism. On the contrary, they theorized, these works were the product of Indian modernism, a unique style expressing the modern Indian identity through the use of traditional visual themes and international aesthetic influences. The exhibition "100 Years of Indian Art" curated in 1994 by Geeta Kapur at the 
National Gallery of Modern Art is commonly considered a turning point-the canon of "Indian modernism" was enshrined in the main national museum. ${ }^{7}$

Aware of this opportunity, auction firms worked to make the new category available through press releases and auction catalogs, in order to promote a financial valuation of the concerned artists (the generations that arose in the 1940s to the 1960s). In 1989, Times of India celebrated its $150^{\text {th }}$ anniversary by exhibiting its collection, part of which was auctioned by Sotheby's in Mumbai. Christie's then opened an office in Mumbai in 1994, and organized its first auction dedicated to "Indian arts" in London in 1995. The same year, Sotheby's organized the first sale exclusively focused on the new category of "Indian modern art" in New York. But the world's two leading auction firms did not really capitalize on the trend, and they would not again organize focused sales until 2003. In the meantime, in 2000, Osian, an auction firm specializing in India and Southeast Asia, and Saffronart, an auction firm specializing in India, were created. The latter developed a long-term strategy around "Indian modern art" in order to compete with Osian and the local branches of Sotheby's and Christie's. Between 1995 and 2001, the average selling price of a work of this category was 6,000 dollars; between 2001 and 2007, it reached 44,000 dollars. In 2007, the category was stable enough to be subdivided into subcategories, and adopted by foreign museums and galleries.

The last characteristic of the Indian art world that is usually emphasized is its segmentation around national boundaries. Although artists feed their work with all aesthetic currents of international art, the distribution channels of their works are either national or foreign. Market expansion in the 1990s and 2000s was mainly carried out within India, and consisted of works by Indian artists bought by Indian collectors. The small segment of Indian experimental artists circulating in foreign galleries and international fairs was not appealing to most Indian buyers. According to Artprice (2011), the hundred top-rated Indian artists in 2011 generated $97 \%$ of sales revenue in the United States and the United Kingdom. ${ }^{8}$ But the situation is somewhat evolving in favor of a double movement. On one hand, the valorization of Indian experimental artists through large group exhibitions in central foreign museums (see below) has also helped to make them visible in India, if only because their growing financial ratings lead galleries to integrate them into their catalogs, and auctioneers to include them in their sales.

On the other hand, the creation of international fairs in Delhi (India Art Fair, since 2008) and Kochi (Muziris Biennale, since 2012) has accelerated the connection between national and international networks, even if most actors feel it is still too slow. Vermeylen (2015) shows that only peripheral foreign galleries have participated in the India Art Fair more than once. Still, they make up $40 \%$ of the represented galleries. Similarly, $60 \%$ of the exhibited artists are Indian. Yet only $60 \%$ among them live in India, and that means $40 \%$ of all the artists are foreign. A number of galleries work to educate Indian customers about foreign artists, and foreign buyers about Indian artists. Furthermore, the few galleries that have reached international networks with "experimental" artists in previous years generally attend these national fairs, contributing to the connection. ${ }^{9}$

\section{Data collection as a heuristic process}

11 Investigating the structure of Indian art galleries' networks has two goals. First, it provides an empirical test of the three characteristics emphasized by the literature with respect to the Indian art world. Did the category "Indian modern art" reorganize how 
gallerists' choose artists? Is the distinction between a national network focused on modern art and an international network focused on experimental art relevant? Is the gallery economy so dependent on the auction market?

Second, as the investigation is conducted systematically and on the broadest possible sample of modern and contemporary visual art galleries, it should provide a typology of Indian art galleries that exceeds usual representations, which are generally based on practical knowledge of only the most renowned galleries. Network analysis helps reformulate the normative distinction between "commercial" and "purist" galleries, or between economic interest and artistic disinterest, in terms of relationships between artists and galleries (Byrnstyn 1978; Moureau and Sagot-Duvauroux 2012). Gallery owners' intentions are often opaque, especially in the field of contemporary visual arts where artistic and economic values tend to be more conflated than in literature or music. In the world of visual arts, gallery owners somehow stand apart from other actors (critics or museums vs. galleries or auctions), and their activities are almost always controversial - "commercial" or, worse, "shopkeeper" remain dismissive insults. But these two scales of value tend toward the same direction with relatively short time intervals. Indeed, artistic valorization raises prices, and in turn rising prices affect artistic reputation (Becker 1986; Velthuis 2005).

13 An important criterion for distinguishing gallery strategies is one of temporality and commitment toward artists. Galleries can provide artists with monetary and reputational resources by storing, exhibiting, or selling their works. The relationship is focused on the valorization of each work, and its temporal scope is limited to the period from the work's acquisition to its (re)sale. Galleries may also represent artist interests with respect to the multiple resource providers in the art world. In such cases, the relationship is focused on the valorization of the artist, which impacts the value of his or her work, and the temporal scope extends to a more or less long sequence (a few years at least) in the artist's career. Galleries usually combine both strategies-they have to value artists in order to sell their works, just as they have to sell works in order to enhance an artist's reputation. But most galleries give priority to either works or artists, to the temporal horizon either of an act of sale or of a career process.

Presenting data collection is important because it offers initial insights. The collection process and the multiple choices made are part of the results. The network analysis is based on Indian art gallery catalogs. Two galleries are considered to be tied when they share at least one artist, and more or less tied according to the number of artists they share. The sample was formed in October 2014 with 101 galleries tied to 4,249 artists. Galleries were selected in two stages. ${ }^{10}$ Several queries were launched on a search engine (such as "art gallery [city]" for the six major cultural cities-Bengaluru, Chennai, Delhi, Kochi, Kolkata, Mumbai $\left.{ }^{11}\right)$. Only galleries displaying a list of associated artists were chosen (all except 3). The list was then compared with several text-based materials: dictionaries, magazines (Take on Art, ArtAsiaPacific, and Art \& Deal), exhibition and auction catalogs, specialized websites (Asia Art Archive, Arslant, the index posted by the Khoj foundation, etc.). ${ }^{12}$ The four galleries not mentioned at least once in this vast literature were eliminated. That decision was a compromise between the desire to base the sample on the point of view of Indian art world actors, and the desire to obtain a substantially larger sample than only the most active or nationally recognized galleries. This sample can be regarded neither as exhaustive nor as representative because the reference population is unknown. ${ }^{13}$ But it covers a number of galleries that no other listing gathers 
and includes parts of the Indian art world's margins. Indeed, no antique or handicraft shops were included, even if they do feature some works recognized as such by the art world. But many selected galleries complement their artistic activity with the trade of antiques and crafts, which may disqualify them as mere "shops" according to the most integrated members of the art world. As a rough estimate, the five editions of the India Art Fair held between 2008 and 2013 invited 87 different Indian galleries. The sample's fourteen remaining galleries represent the margins of the Indian modern and contemporary art world.

The other part of the sample consists of all the artists that these 101 galleries displayed in their catalogs (in October 2014). Artists showcased in these catalogs represent very different relationships, degrees of economic and reputational risk, and commitment on the part of galleries. None were excluded, but for the analysis to be meaningful, they were coded into four categories: representation (of interest) when the artist is tied exclusively and permanently to a gallery, ${ }^{14}$ storage (of works) when a gallery has bought works from the artist in order to offer them for sale, ${ }^{15}$ exhibition (of works) when a gallery organizes exhibitions or makes its facilities and name ${ }^{16}$ available for exhibitions, ${ }^{17}$ promise (of works) when a gallery's catalog displays works and/or artists without representing, storing, or exhibiting them. Note that economic risk is not reputational risk: "stock" strategies need more business capacity but are less indicative of an intent to invest in emerging talents or uncommon aesthetics (stocks have to be sold one day), "representation" strategies imply a hazardous long-term commitment to develop new artists, and "exhibition" strategies make it easier to test innovations (they involve less time/money investment and therefore fewer consequences if they fail).

The latter category ("promise") is problematic but important even if it concerns only a small part of the sample (only four of 101 galleries displayed exclusively "promise" relationships, accounting for 502 of the 9,879 bonds between artists and galleries). It refers to the promise made to potential buyers that the gallery is able to provide the works presented even if it has no link yet with the artist, the artist's beneficiary, or the work's owner. It therefore leads to bluffing techniques-presenting an inaccessible work to attract buyers and offer them other works. Almost all galleries use this technique, but few do so exclusively since it can create a perception of dishonesty. Even when genuine, it is still publicly considered to be illegitimate because it is seen as a one-way relationship, with no commitment from the gallery to the artist-with no economic or reputational risks. However, the promise of a gallery's ability to offer a prestigious work to the public can be seen as a way of elevating the gallery's market status, and that in turn is thought to contribute to the visibility and hence the reputation of the artist. Thus, some galleries tend to essentially promise renowned artists, helping to strengthen their membership in the artistic canon, while others promise mostly unknown artists, offering a kind of first step of public recognition.

This ambivalence toward the "promise" technique (frowned upon but used) reflects the fiduciary (or circular) nature of the construction of values in the art world (Bourdieu 1971). The act of claiming a recognized artist serves to certify the value of the gallery, and a gallery's claim certifies the value of the artist: these value transfers do not necessarily imply a material exchange or risky commitment, but they do associate two names (the fundamental unit of value in the art world) in the same physical space of public visibility (websites, shop windows, printed catalogs). In the sample, galleries exclusively offering such relationships were classified as favoring "promise"; there are 
only four in total. The category allows us to observe, for example, a gallery's degree of artistic recognition or participation in the auction market. But ideally every gallery should be characterized by the part left to such relationships: they almost all offer promises, in addition to the artists they represent, store, and/or exhibit. But, by definition, it is impossible to quantify these ties since it would require checking every promise work by work-the art of bluffing is based on this difficulty.

\section{Galleries and artists in the sample: first insights}

Several sets of information were then collected on the galleries and their artists. For galleries, in addition to the city: manager name and sex, the year of creation, participation in at least one of the five editions of the India Art Fair between 2008 and 2013, and the type of access to the catalog offered to the public (a shop in a mall, a shop on a city street, a room or a shop in a gated community residence, access by appointment only, or by a website only).

Table 1. Galleries' main relationships with their artists by gallery director sex, access, period of creation, participation in the India Art Fair

\begin{tabular}{|c|c|c|c|c|c|c|}
\hline \multirow{2}{*}{\multicolumn{2}{|c|}{ (numbers) }} & \multicolumn{4}{|l|}{ Relationships } & \multirow{3}{*}{\begin{tabular}{|l|} 
Tota \\
7
\end{tabular}} \\
\hline & & \multirow{2}{*}{$\begin{array}{l}\text { Representation } \\
2\end{array}$} & \multirow{2}{*}{\begin{tabular}{|l|} 
Stock \\
4
\end{tabular}} & \multirow{2}{*}{\begin{tabular}{|l} 
Exhibition \\
1
\end{tabular}} & \multirow{2}{*}{ Promise } & \\
\hline \multirow{3}{*}{ Directors' sex } & Male and female & & & & & \\
\hline & Female & 13 & 18 & 23 & 1 & 55 \\
\hline & Male & 11 & $12^{18}$ & 13 & 3 & 39 \\
\hline \multirow{5}{*}{ Access } & Appointment & 2 & 3 & & & 5 \\
\hline & $\begin{array}{l}\text { Gated } \\
\text { community }\end{array}$ & 9 & 13 & 15 & & 37 \\
\hline & Mall boutique & 3 & 5 & 7 & & 15 \\
\hline & Street boutique & 12 & 13 & 15 & 1 & 41 \\
\hline & Website & & & & 3 & 3 \\
\hline \multirow{5}{*}{ Creation } & $80-$ & 1 & 4 & & & 5 \\
\hline & $80-91$ & & 2 & & & 2 \\
\hline & 91-00 & 2 & 6 & 5 & & 13 \\
\hline & 00-08 & 7 & 5 & 4 & 1 & 17 \\
\hline & $09+$ & 16 & 17 & 28 & 3 & 64 \\
\hline India $\quad$ Art $\quad$ Fair & No & 4 & 11 & 20 & 3 & 38 \\
\hline
\end{tabular}

2008-13 


\begin{tabular}{|l|l|l|l|l|l|l|}
\cline { 2 - 7 } & Yes & 22 & 23 & 17 & 1 & $\mathbf{6 3}$ \\
\hline Total & 26 & 34 & 37 & 4 & $\mathbf{1 0 1}$ \\
\hline
\end{tabular}

Table 1 summarizes information about galleries. Several results immediately stand out. First, there is a strong correlation between participation in the India Art Fair and the types of bonds that exist between galleries and artists. Of "promise" galleries, three in four never participated in the fairs. More than half of galleries favoring "exhibition" never participated in the fairs. But that was only the case of a third of "stock" galleries, and of less than a fifth of "representation" galleries. A major indicator of the relative legitimacy of the different relationships between galleries and artists in the art world: the more gallery involvement, the more the relationship-in terms of artistic recognition-is perceived to be legitimate by market actors (galleries and collectors).

Second, Indian gallery managers are mostly women, this being especially true for "stock" and "exhibition" galleries. Occupations in the art world offer a legitimate way of working outside the domestic sphere for elite women, who tend to be more excluded from professional activities than men. The variation is difficult to interpret but two hypotheses suggest themselves. Gallery strategies that imply a lot of contact with artists and other actors, such as representation compared to exhibition and storage, are less likely to be open to women-a kind of "etiquette" hypothesis. Or: women are more represented than men in "stock" and "exhibition" galleries, which activity is more considered as economic, because these galleries are more often funded by industrial families, where women willing to have a professional activity are more often oriented toward "secondary" activities, like running a gallery. This could also explain why four couples out of seven manage "stock" galleries-but I do not have sufficient information on managers' families to corroborate this explanation.

21 Third, in terms of access, the five galleries offering visits by appointment only are on the side of the riskiest relationships (stock and representation), and the galleries offering access only by internet are on the side of the least risky relationships (promise); "exhibition" galleries are logically concentrated on public modes of access ("street," "mall," "gated").

Fourth, "representation" has increasingly become the preferred strategy, which correlates with recent changes in the Indian art world: what is sometimes seen as a kind of "professionalization" of Indian galleries relates to an increasing appropriation of the normative model that dominates renowned international fairs-the gallery with "its" pool of exclusive artists.

23 For artists, several sources were used. The Saffronart search engine-the main Indian auction firm-provided a list of artists already included in a sale and the highest sale price achieved by an artist, and year of birth. India Art Fair catalogs from 2008 to 2013 provided a list of the artists exhibited and/or represented at least once, artists who were considered worthy to contribute to the artistic reputation of the gallery-an artistic reputation indicator. The online index of activities organized by the foundation KHOJ, since its inception in 1997 to October 2014, provided a list of artists involved in the network that the foundation is building, focused on contemporary "experimental" art and favoring dependency on public and private patronage rather than on the auction market. 
24 Artists were then classified according to their membership in three aesthetic canons attached to three successive periods. The Dictionary of Indian Art \& Artists published by Pratima Seth (2006) provided a list of artists commonly accepted as belonging to the pantheon of modern art (176 of almost 500 artists included in the dictionary are part of the sample). This dictionary was chosen for its extensiveness, quality, ${ }^{19}$ and year of publication-2006, before the market boom and the internationalization of some contemporary artists. Covering the period from the 1890s to the early 2000s, the dictionary is logically centered on "modern" and "abstract" (see below) canons, although it also includes some pioneering figures of "experimental" art from the 1970s.

The catalogs of 15 international exhibitions on "Contemporary Indian Art" in foreign museums between 1998 and $2011^{20}$ then provided a list of artists included in the pantheon of contemporary art labeled "experimental" ${ }^{21}$ here. Among 126 artists exhibited in at least one of these 15 shows, 67 were selected only once, 31 two or three times, 28 four times or more (up to 13 times)-and they are all part of the sample.

Since some artists are included in both "modern" and "experimental" lists, they have been classified in a third category. Indeed, they appear to be the "masters of Indian art" associated with the Independence period. The three resulting categories are roughly delimited, and are temporal more than aesthetic: "modern" refers to the styles invented before World War II (fauvism, cubism, surrealism, etc.), "abstract" to the styles invented in the 1940s and 1960s (abstract expressionism, lyrical abstraction, art brut, serial art, etc.), "experimental" to the styles developed beginning in the 1970s (conceptual art, minimalism, installation, happening, arte povera, feminist art, monumental works, etc.). Table 2's caption provides some of the artist names. All statistical results presented further on confirm the relevance of this classification. Although it is aesthetically crude, it clearly distinguishes contrasting artistic profiles. 
Table 2..22 Artists' membership to canons by higher bid at Saffronart's auctions, ${ }^{23}$ birth period, participation at the India Art Fair 2008-2013, participation in Khoj's activities

\begin{tabular}{|c|c|c|c|c|c|c|}
\hline \multirow{2}{*}{\multicolumn{2}{|c|}{ (numbers) }} & \multicolumn{4}{|c|}{ Canon } & \multirow{3}{*}{\begin{tabular}{|l|} 
Total \\
3,282 \\
\end{tabular}} \\
\hline & & \multirow{2}{*}{$\begin{array}{c}\text { Experimental } \\
30\end{array}$} & \multirow{2}{*}{\begin{tabular}{|c|} 
Abstract \\
2 \\
\end{tabular}} & \multirow{2}{*}{\begin{tabular}{|c|} 
Modern \\
53 \\
\end{tabular}} & \multirow{2}{*}{\begin{tabular}{|c|} 
no \\
3,197 \\
\end{tabular}} & \\
\hline \multirow{7}{*}{$\begin{array}{c}\text { Higher bid at } \\
\text { Saffronart } \\
\text { (rupees) }\end{array}$} & No auction & & & & & \\
\hline & $0-96,000$ & 14 & 14 & 72 & 516 & 616 \\
\hline & $\begin{array}{l}96,000- \\
340,000\end{array}$ & 7 & 6 & 9 & 114 & 136 \\
\hline & $340,000-$ & 10 & 9 & 17 & 54 & 90 \\
\hline & \begin{tabular}{|l}
$977,000-$ \\
\end{tabular} & 18 & 11 & 15 & 21 & 65 \\
\hline & & & & & & \\
\hline & $\begin{array}{l}\text { more than } \\
4,025,000\end{array}$ & 21 & 23 & 10 & 6 & 60 \\
\hline \multirow{6}{*}{ Born } & 19th & & & 10 & 5 & 15 \\
\hline & $1900-45$ & 4 & 38 & 70 & 63 & 175 \\
\hline & $1960 \mathrm{~s}$ & 38 & 23 & 43 & 341 & 445 \\
\hline & 1970 s & 26 & & 1 & 245 & 272 \\
\hline & $1980 \mathrm{~s}$ & 2 & & & 55 & 57 \\
\hline & NA & 30 & 4 & 52 & 3199 & 3,285 \\
\hline \multirow{2}{*}{ IAF 2008-13 } & no & 23 & 11 & 100 & 3286 & 3,420 \\
\hline & yes & 77 & 54 & 76 & 622 & 829 \\
\hline \multirow{2}{*}{ Khoj activities } & no & 45 & 55 & 174 & \begin{tabular}{|l|l}
3808 \\
\end{tabular} & 4,082 \\
\hline & yes & 55 & 10 & 2 & 100 & 167 \\
\hline \multicolumn{2}{|c|}{ Total } & 100 & 65 & 176 & 3908 & 4,249 \\
\hline
\end{tabular}

SOME ARTIST NAMES MIgHT HELP READERS FRAME THE THREE PERIODS.

THE 21 BEST SOLD ARTISTS IN THE “EXPERIMENTAL CANON": ALWAR BALASUBRAMANIAM, ANITA DUBE, ANJU DODIYA, BHARTI KHER, GR IRANNA, HEMA UPADHYAY, JAgANNATH PANDA, JAYASHREE CHAKRAVARTY, JITISH KALLAT, JUSTIN PONMANY, LN TALLUR, NS HARSHA, NATARAJ SHARMA, RAMESHWAR BROOTA, RANBIR SINgH KALEKA, RASHID RANA, SHIBU NATESAN, SUBODH GUPTA, SURENDRAN NAIR, TV SANTHOSH, THUKRAL \& TAgRA.

THE 23 BEST SOLD ARTISTS IN THE "ABSTRACT CANON": AKBAR PADAMSEe, ANJOLIE ELA MENON, ARPITA SINGH, ATUL DODIYA, BHUPEN KHAKHAR, BIKASH BHATTACHARJEE, CHITTROVANU MAZUMDAR, G RAVINDER REDDY, GANESH PYNE, GULAMMOHAMMED SHEIKH, HIMMAT SHAH, JEHANgIR SABAVALA, JOgEN CHOWDHURY, KG SUBRAMANYAN, KRISHEN KHANNA, MANJEET BAWA, NILIMA SHEIKH, PARAMJIT SINGH, RAM KUMAR, S H RAZA, SUDHIR PATWARDHAN, THOTA VAIKUNTAM, TYEB MEHTA. THE 10 BEST SOLD ARTISTS IN THE "MODERN CANON": AMRITA SHER GILL, B PRABHA, KH ARA, KK HEBBAR, MEERA MUKHERJEE, NS BENDRE, NASREEN MOHAMEDI, RABINDRANATH TAgORE, SAKTI BURMAN, VS GAITONDE.

Among the 4,249 artists, 176 belong to the "modern" cannon, 65 to the "abstract" cannon, and 100 to the "experimental" canon (Table 2). Their years of emergence are not surprising, with the pivotal period of the first half of the twentieth century, extended through the 1960s because successful pioneering innovations are always followed by dominance and imitation. The artists of the "abstract" canon are "stars" on the auction market: only two have never been auctioned by Saffronart, and a third obtained the highest prices. "Modern" and "experimental" canonized artists are auctioned in the same proportions (just over two thirds) but their prices are distributed very differently. "Modern" canonized artists sell comparatively more cheaply, with only $41 \%$ reaching the first price class. "Experimental" canonized artists sell generally cheaper than "abstract" artists but garner significantly higher prices than "modern" artists, with 39\% reaching the two highest price classes. 
Finally, presence at a minimum of one India Art Fair (IAF) and at least one Khoj activity (workshop, exhibition, conference, training, etc.) confirms the relevance of the canon classification. Attendance at fairs concerns more than half of all canonized artists: it is a good index of artistic recognition. In addition, the relative presence of each canon reflects gallery strategies. "Modern" canonized artists place galleries inside the prestigious tradition of Indian art, but they are not distinctive and they are sold at comparatively low prices. That is why only $43 \%$ of these artists have been exhibited at IAF. "Abstract" canonized artists are the stars of sales: $83 \%$ have been exhibited at IAF. Finally, "experimental" canonized artists enable galleries to be part of recent dynamics and "trends," but they are riskier (the canon is not yet stabilized) and their prices are lower than "abstract" artists: $77 \%$ of them have been exhibited at IAF. Fairs are par excellence the place for galleries to establish their reputation, embodying the association of artistic recognition and monetary value. Beyond differences between galleries, IAF reveals their three strata of strategies: a stable base of less profitable "modern" artists that provide an anchor for posterity; a profitable core of "abstract" artists who establish gallery reputations and garner high prices on the domestic market; a more evolving set of "experimental" artists put on the market in the hope of a value increase.

"Abstract" and "experimental" canonized artists differ both in terms of relative prices, as we have seen above, and even more so through their participation in Khoj activities. "Modern" canonized artists, mostly dead, obviously do not participate. However, few "abstract" canonized artists, who are mostly still alive (only 12 of the 65 had died before 2014) participate either-less than a quarter of them. While more than a half (55\%) of "experimental" canonized artists have contributed at least once. The association with Khoj is an indicator of belonging to "experimental" networks that dominate the world of international contemporary art.

\section{Methodology}

30 A typology of galleries cannot be achieved through the study of correlations between the different variables taken by pairs-whether through bivariate or regression analyses. Geometric (or factorial) analysis would do in principle but only if more data were available regarding galleries and artists. For $65 \%$ of the artists sampled, no information other than their links to galleries is available. Geometrical analysis would only serve to oppose these artists against all others, from the least recognized (but still present in the fairs, Khoj activities, or Saffronart auctions) to the stars. In terms of galleries, only participation at the India Art Fair is indicative of value. To be sure, other information is discriminating, but only if associated with value indicators concerning their artists-and $65 \%$ of them do not have them. The only interesting test was to select a sub-sample of artists based on who had been auctioned by Saffronart at least once. A hierarchical cluster analysis (HCA) performed on a multiple correspondence analysis (MCA) confirmed the significance of each of the variables as well as their correlations as seen with previous bivariate analyses (see Appendix 1). But their interest is limited, if only because the number of available variables is relatively small; compared to bivariate analysis, the gain in synthesis is low. In addition, since most artists are associated with several galleries, it is difficult to include them in this type of calculation. More importantly, it reduces the analysis to the top of the market, or less than a quarter (23\%) of the sample. This excludes 
one of the main distinctions between galleries: the proportion of artists not (yet) recognized in their catalog.

31 The only way to find distinctive groups of galleries from the whole sample is then to put aside gallery and artist characteristics, and to adopt Accominotti's (2008) methodology, basing calculations on the bonds between artists and galleries. In other words, which galleries share artists through their catalogs, how many are shared, and whose artists are shared. Artist and gallery characteristics can then be reintroduced to interpret the resulting representation of gallery networks, despite the relative poverty of that information. As shown by Accominotti (2008), catalog choices are at the heart of galleries' business, and the sharing of artists reflects proximities and distances in the art world. In the case studied by Accominotti, these proximities and distances are structured according to a hierarchy of reputational status on the market.

32 Once this methodological principle was established, a way of calculating these proximities and distances in the network still needed to be chosen. There has been no attempt here to study network properties (density, betweenness, etc. ${ }^{24}$ ). Rather, the aim has been to group galleries according to their relative distances in the network. Producing such an interpretable typology means choosing a method for partitioning the network. The tests revealed three interesting methods, each one producing information about the structuring of gallery space that others do not-it thus maximized the relatively poor amount of available information on gallery and artist properties. Two of the methods and their results are presented briefly in the appendices. The first method, presented above, is not a network but a geometrical analysis (multiple component analysis). It reveals the main independent factors differentiating the artists who have been auctioned by Saffronart at least once-their period of activity, and their market value (Appendix 1). The second method is based on degrees in gallery networks: clusters are calculated depending on the number of links each gallery has with other galleries through the sharing of the same artist(s). Degrees are a rough but interesting method: galleries are merely ordered according to their presence on the auction market, which is correlated with their relationship to canonized abstract and modern artists; meanwhile, galleries which least share artists may be either small commercial or regional dealers, or internationally renowned galleries representing experimental artists (Appendix 2). The third method, presented in the next section, is the most fruitful, offering a refined and multi-dimensional typology.

\section{More or less equivalent positions}

Blockmodeling gathers galleries that have a similar position with respect to all other galleries. The partition is thus based on the structural equivalence of positions in the network. The chosen algorithm ${ }^{25}$ calculates a similarity score between network nodes: two vertices are structurally equivalent if they are connected in the same way to the same other vertices. This means that two galleries may belong to the same class even if they share very few or even no artists; they just share the same artists with the same other galleries, and no artists with the same other galleries. A hierarchical classification tree was then produced, which was divided according to the desired number of classes. Mathematical indices are available but they are relatively redundant in light of a visual assessment of the relative distance between successive intersections of the tree. A second algorithm ${ }^{26}$ divides the chosen clusters and reduce ${ }^{27}$ them according to several possible 
calculations-here, the aim was to find the most cohesive clusters, according to density based on the average value of each block. Table 3 shows the resulting typology of galleries with the characteristics most associated with each block-for the written descriptions above, some simple cross-tabulations are also used.

Table 3. A typology of 101 Indian art galleries through the network of their shared artists

\begin{tabular}{|c|c|c|c|c|c|c|c|}
\hline & & Established & Purist & Consecrated & Peripheral & Regional & International \\
\hline \multicolumn{2}{|c|}{ Characteristicts } & Block 1 (50) & Block 2 (16) & Block 3 (12) & Block 4 (12) & Block 5 (8) & Block 6 (3) \\
\hline \multirow{8}{*}{ Galleries } & $\begin{array}{l}\text { Main link with } \\
\text { artists }\end{array}$ & stock & representation & no corr. & $\begin{array}{c}\text { no corr. (promise, } \\
\text { exhibition) }\end{array}$ & $\begin{array}{l}\text { promise, } \\
\text { exhibition }\end{array}$ & representation \\
\hline & Sex & no corr. (female) & no corr. (male) & no corr. (female) & no corr. (male) & male & no corr. (female) \\
\hline & City & Kochi & Chennai, Kolkata & Kochi, Kolkata & Chennai, Bengaluru & $\begin{array}{c}\text { Kochi, Kolkata, } \\
\end{array}$ & Mumbai \\
\hline & Access & $\begin{array}{c}\text { no corr. (gated, } \\
\text { mall) }\end{array}$ & no corr. & $\begin{array}{c}\text { no corr. } \\
\text { (appointment, } \\
\text { street) }\end{array}$ & web, mall & web, street & no corr. (street) \\
\hline & Open & Before 2000 & $\begin{array}{c}2000-2008,1991 \\
z 000\end{array}$ & no corr. (after 2000) & $\begin{array}{c}\text { no corr. (before } \\
1980 \text {, after 2009) }\end{array}$ & after 2009 & $1991-2000$ \\
\hline & IAF 2008-13 & $25-75 \%$ & $75-100 \%, \theta-25 \%$ & $75-100 \%, 0-25 \%$ & $0-25 \%$ & $0-25 \%$ & $75-100 \%$ \\
\hline & $\begin{array}{c}\text { Overlapping quartile } \\
\text { (degrees) }\end{array}$ & 3 and 4 & 1 & 2 & 2 & 1 & 1 \\
\hline & $\begin{array}{l}\text { Overlapping cluster } \\
\text { (HCA) }\end{array}$ & 1 and 2 & 3 & 3 & 1 & 1 & 3 \\
\hline \multirow{6}{*}{ Artists } & No auction & $0-50 \%$ & $50-75 \%, 0-50 \%$ & no corr. $(0-25 \%)$ & no corr. $(50-75 \%)$ & $75-100 \%$ & $0-25 \%$ \\
\hline & Highest bids & $25-50 \%$ & $25-50 \%$ & $50-75 \%$ & no corr. $(0-25 \%)$ & no corr. $(0-25 \%)$ & $25-50 \%, 0-25 \%$ \\
\hline & Khoj activties & $0-25$ & no corr. $(25-75 \%)$ & $25-50 \%$ & no corr. $(0-25 \%)$ & no corr. $(0-25 \%)$ & $50-75 \%$ \\
\hline & Modern canon & $12-23 \%, 35-46 \%$ & $0-12 \%$ & $0-12 \%$ & $23-35 \%$ & no corr. $(0-12 \%)$ & no corr. (0-12\%) \\
\hline & Abstract canon & $10-30 \%$ & $0-10 \%$ & $30-40 \%$ & $0-10 \%$ & $0-10 \%$ & no corr. $(10-20 \%)$ \\
\hline & Experimental canon & $16-64 \%$ & no corr. (16-64\%) & $16-32 \%$ & no corr. (0-16\%) & no corr. $(0-16 \%)$ & $32-64 \%$ \\
\hline
\end{tabular}

VALUES ARE THE CATEgORIES THAT ARE SIgNIfICANTLY CORRELATED TO EACH BLOCKMODEL, ACCORDING TO PEARSON'S RESIDUALS. IT IS BASED ON CHI-SQUARE BUT IT MEASURES THE OVERREPRESENTATION OF EACH CROSSING OF CATEgORIES FROM VARIABLES (HERE, BLOCKMODELS AND gALLERIES' OR ARTISTS' CHARACTERISTICS). IT IS USUALLY CONSIDERED AS SIgNIFICANT WHEN OVER 1,96 OR ABOVE $-1,96$.

HERE, THE LINE THROUgH IS FOR NEgATIVE CORRELATIONS. WHEN RESIDUALS ARE BETWEEN -1,96 AND 1,96, POSITIVE CORRELATIONS ARE STILL PUT IN BRACKETS WHEN DISTINCT FROM OTHERS (COMPARE $0,12 ;-0,7 ; 0,85$ TO $-0.24 ;-0,38 ;-0,27)$.

OVERLAPPINg QUARTILES AND CLUSTERS (ITALIC) ARE NOT MEASURED BUT RESULT FROM THE COMPARISON BETWEEN THE LISTS OF gALLERIES BELONgINg TO EACH gROUP.

Percentages are those of equal classes (0/25/50/75/100\%) or quartiles. Eg, Block 1 is significantly correlated with galleries where $25-50 \%$ or $50-75 \%$ of the artists were exhibited or represented at India Art Fairs between 2008 and 2013. It is also significantly correlated with galleries where 12-23\% or $35-46 \%$ of the artists belong to the modern canon.

The first block considers established galleries. It represents 50 of the 101 galleries, and is the most heterogeneous. Established galleries are only those that determine the modal profile of the block. They opened before 2000, and they represent half of the galleries opened before 1980. They have large stocks that they regularly exhibit, with a high level of activity on the auction market (but they do not garner the highest rates). Many of their artists are thus part of the modern conceptual canon, but very few belong to the experimental canon, and very few are related to Khoj activities. Their presence at the India Art Fair is variable, from weak to strong. It reveals that sharing the same "auctionable" artists may be associated with artistic prestige, for old and established galleries (like those located in Kolkata, the previous cultural capital of colonial India), or with a peripheral position, for galleries merely focused on auction trade.

Galleries of block 1: Akar Prakar; Art Indus; Creativity Art Gallery; Idiyas Gallery; Janus Art Gallery; Tao Art Gallery; Art Elements; Art Heritage Gallery; Art Konsult; Art Musings; Chawla Art Gallery; Crimson Art Gallery; Delhi Art Gallery; Dhoomimal Art Centre; Emami Chisel Art; Forum Art Gallery; Galerie 88; Galleria; Gallery Art and Soul; Gallery Time \& 
Space; Ganges Art Gallery; Genesis Art Gallery; Kumar Gallery; Prakrit Art Gallery; Pundole Art Gallery; Renaissance Art Gallery; Visions Art; Aakriti Art Gallery; Apparao Galleries; Art Alive Gallery; Arushi Arts; Center of International Modern Art; Cymroza Art Gallery; Gallerie Nvya; Gallery 7; Gallery Alternatives; Gallery Art Motif; Gallery Art Positive; Gallery Beyond; Gallery Espace; Gallery Kolkata; Gallery Sumukha; Gallery Threshold; Mon Art Gallery; Palette Art Gallery; Polka Art Gallery; Sarala's Art Centre; Studio 3; The Arts Trust; The Viewing Room

The second block mainly encompasses purist galleries, which are concentrated in Mumbai and Delhi and represent a small number of artists in long-term relationshipsrepresentation is the main link with artists for all but 1 of the 16 galleries belonging to this block, which concentrates $57 \%$ of representation links. All galleries were created after 2000 and have a strong presence at the India Art Fair. Their artists are rarely auctioned but often participate in Khoj activities. They are also more likely to be members of the experimental canon, and overall they are rarely members of modern or abstract canons.

Galleries of block 2: Abadi Art Space; Ashish Balram Nagpal Galleries; Chatterjee \& Lal; Exhibit 320; Experimenter; Galerie Mirchandani + Steinruecke; Gallery Maskara; GallerySKE; MK Search Art; Photoink; Project 88; Seven Art Limited; Talwar Gallery; Tasveer Gallery; Volte; Wonderwall

The third block is that of recognized galleries. Created after 2000, they are the most present on the auction market, often receiving the highest bids, so that many of their artists are part of the experimental and especially abstract canons-the most lucrative on the market, as seen above. They are also very present at the India Art Fair. Indeed, they tend to be less exclusively focused on auctions and sales than block 1 , and have built an artistic reputation that makes them aesthetically prescriptive. It is in this sense that they combine work storage and artist exhibitions with long-lasting representation of some artists whom they accompany throughout their careers (which results in "no correlation" with any category), including some young, aspiring artists whom they launch on the market-hence the strong presence of artists contributing to Khoj activities.

Galleries of block 3: Amrita Jhaveri Projects; Chaithanya Art Gallery; Focus Art Gallery; Gallery Ragini; Shrine Empire Gallery; The Guild; The Loft at Lower Parel; Vadehra Art Gallery; Crayon Capital Art; Kashi Art Gallery; Sakshi Gallery; Latitude 28

The galleries of the fourth and fifth blocks are presented together as they show two similar profiles. Above all, they have in common their lack of artistic and economic resources, and thus can be considered peripheral galleries. They are small, young galleries absent from auctions and the Indian Art Fair, mainly located in the outlying cities of the Indian art world-galleries we can also call regional. Block 4 appears slightly "over" block 5 because three of its galleries present a slightly different profile: they are young but nevertheless have already accessed some works of the modern canon, and they represent some living artists dedicated to "modern" aesthetics. Thus, block 4 can be called peripheral, and block 5 , regional.

41 Galleries of block 4: The Stainless Gallery; Artland; Dhoomimal Gallery; Gallery Sri Parvati; International Creative Art Centre; Kynkyny; Mahua; Nitanjali Art Gallery; The Faraway Tree; Verandah Art Gallery; Vinnyasa Premier Art Gallery; Masters Collection Art Gallery 
Bajaj Art Gallery; Kolkata Art House; Mirage Art Gallery; Studio Palazzo; Vernissage Gallery

Finally, the sixth block brings together three galleries with an original profile: they are recognized purist galleries which have access to international art networks-they can therefore be called international galleries. Two of them were established in Mumbai in the 1960s or after 2008, another in the 1990s in Delhi. Devoted India Art Fair attendees (they also frequent international fairs abroad), they have built their business around a group of artists they represent over time, who are very present in auctions, within the experimental canon (sometimes the abstract one), and among Khoj's contributors at the same time. (lowest degrees) covers galleries that are exclusively members of blockmodels 2, 5, and 6 (and one from blockmodel 1): purist galleries and international galleries focused on exclusive representation, and regional galleries dealing with small distribution catalogs. Meanwhile, the HCA clearly distinguishes both types according to their auction market position. The second quartile includes most members of blockmodels 3 and 4, and 6 from blockmodel 1: recognized and peripheral galleries (and some established), all galleries that mix shared artists with their "own" artists (because they represent them exclusively, or because these are regional artists). The third and fourth quartiles gather almost all members of blockmodel 1 (and some from blockmodels 3 and 4): established galleries, those competing for the trade of "auctionable" artists, who are often shared, with their works being stored or exhibited.

The HCA distinguishes all these more or less valued galleries according to their period specialization (modern and abstract vs. experimental). All galleries of blockmodel 6 (international), almost all of blockmodel 3 (recognized), and a large part of blockmodel 2 (purist) are present in cluster 3 (valued experimental artists). All galleries of blockmodels 4 (peripheral) and 5 (regional) are present in cluster 1 (lesser valued artists, but auctioned at least once). Blockmodel 1 (established) is distributed over clusters 1 and 2, cluster 2 (valued modern or abstract artists) being almost completely filled with blockmodel 1.

\section{An art world centered on the auction of national decorative identity?}

Blockmodeling thus offers a richer typology of Indian art galleries, synthesized in Table 3 and Figure 1-this latter also takes into account information from HCA and partition by degrees.

South Asia Multidisciplinary Academic Journal, 15 | 2017 
Figure 1. Graphic summary of Indian art gallery typologies

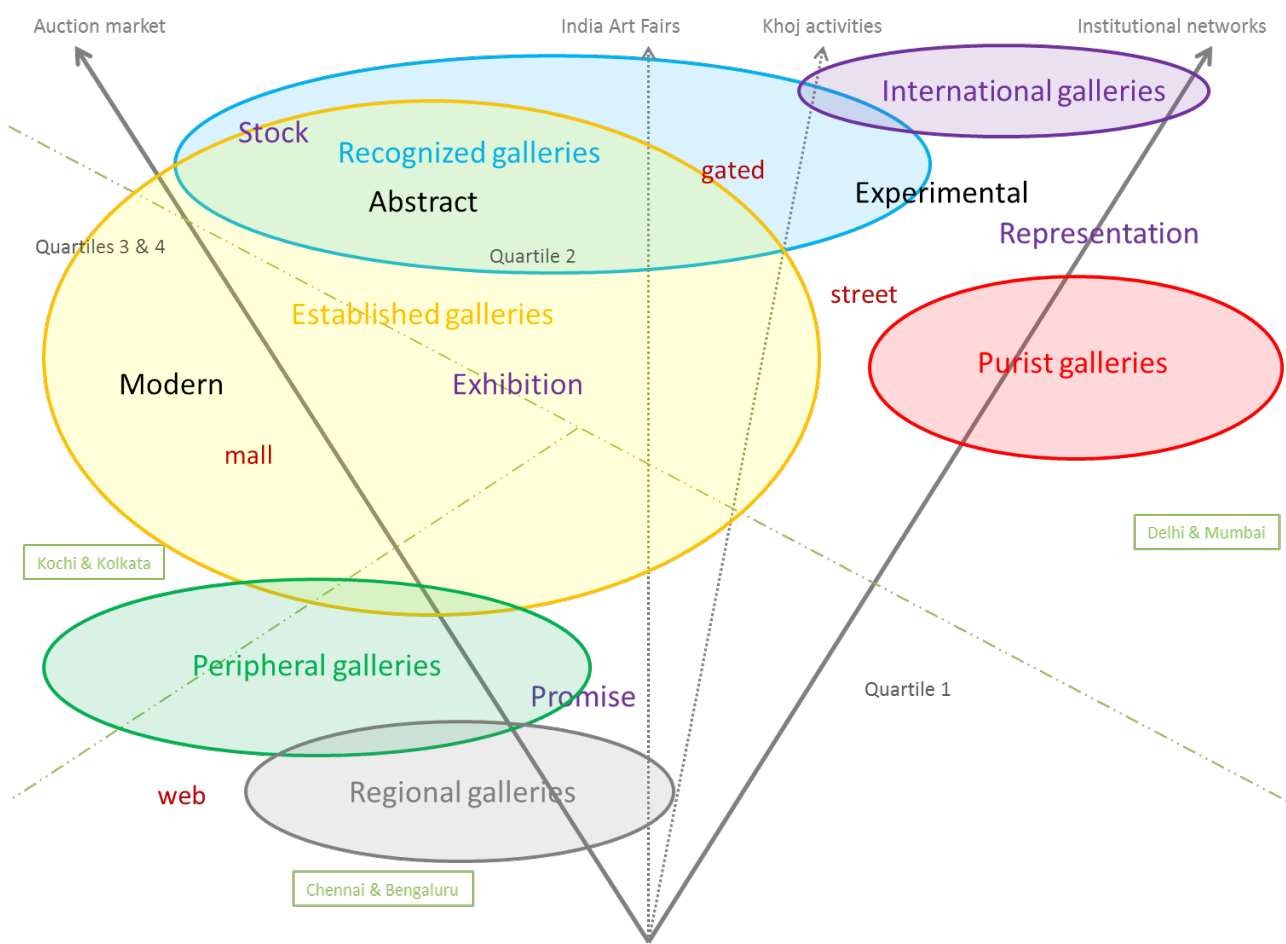

LEgEND:

Delhi \& Mumbai $\quad$ Gallerylocated in

web Access to gallery

Purist galleries Type of gallery (blockmodel)

Exhibition Main relation between gallery and its artists

Modern Artistic canon

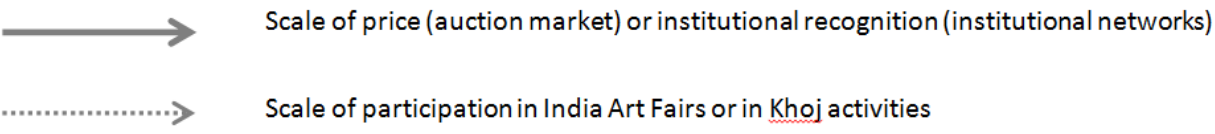

Figure 1 is more reductive than Table 3, but may be easier to read. Intelligible graph making implies simplifying information. Here, the simplifying interpretation is oriented toward an emphasis on the most prominent properties of the data. In that sense, it makes the main correlations revealed by the analysis and synthetized by blockmodeling apparent. First, there is a strong relation, on one hand, between experimental aesthetics, representation of artists, and institutional networks (in the sense of a scale of recognition different from auction prices), and, on the other hand, between abstract aesthetics, storage of artists, and the auction market. Second, the India Art Fair is a place where all 
types of galleries gather, except some peripheral and regional ones. The fair represents a kind of compromise between market and institution, reflecting the compromises that galleries make every day as art intermediaries when they convert artistic value into economic value, and vice versa. Third, Indian art galleries seem to be merely focused on the auction market. Galleries are mainly ordered by their position on the scale of auction prices: at the top, on its margins, or outside ("outside" meaning what has been excluded from this simplified picture: international and purist galleries do participate in the auction market, but they also deal with another scale of value, where artistic reputation through institutional and international networks appears as a bet on future economic valorization and/or aesthetic canonization).

These results offer substantive insight into the Indian cultural elite, based on the assumption that art galleries are one of the providers of symbolic goods for the "happy few" that prescribe aesthetic norms to cultural and economic upper classes (Bourdieu 1979). First, the symbolic, social, and economic boundary between "Indian modern art" (which includes both modern and abstract canons) and international "experimental" art engenders an ambiguous image of Indian cultural elite standards. On the one hand, it appears as a collective ability to define its own aesthetic norms, independently from Western prescriptions. From that perspective, the Indian state, its focus on heritage more than living artists, and its decisive role in training and legitimizing young, aspiring artists, may play an important role despite the denegation of most of the market's private actors-an ideological disqualification of public institutions that is commonly considered a common value of new upper classes (Fernandes 2000). On the other hand, the Indian market for modern and contemporary art is quite small considering the size of Indian upper classes, and its focus on "Indian modern art" may merely be the result of its relative proximity (compared to experimental art, which often does not fit in a living room) to traditional crafts, antiques, and classical decorative features-the "heritage" part of the market that feeds into the ruling elite's status signals. In other words, modern and contemporary visual arts may reveal only a part of the symbolic goods that constitute the Indian elite's decorative standard.

50 Second, the expansion of the market, beginning in the 2000s and despite the 2008-2011 crisis, means that more and more money is being invested in the arts-visual artworks are also financial assets, and the weight of the auction market makes this particularly true for India. This may be another explanation for the collective preference for Indian modern art. As financial assets, art works that remain inside the national boundaries are more accessible, and easier to buy and sell. Modern art can also be used to launder money -perhaps another social role of the arts for some elites. By definition, such a claim is almost impossible to investigate. But legal cases regularly show that visual artworks are an effective way of laundering money, simply because there is no standardized scale of price (the social arbitrariness of cultural taste makes it easy to overvalue works), and a strong stability of recognized artists (the first good sale makes them sure bets).

\section{Conclusion}

51 Existing analyses of the Indian art world tend to focus on the top of the art market, basing themselves entirely on qualitative data. Some are thus more refined than this study. However, they miss what systematic quantitative data, which include the margins of the market, can offer: an empirically grounded description of the main structuring factors of 
this social world. Future analysis may obviously benefit from qualitative inquiries: about informal transactions and sociability, about the relations with buyers and collectors, about the chains of cooperation needed for making, carrying, promoting, selling, and exhibiting works, about aesthetic subdivisions and innovations, etc. But the main weakness of the present study-as I see it-is the relative poverty of its information. I hope to convince readers that statistical tools used with large sets of data can produce knowledge from a small number of rough variables. Still, completing the data with systematic information would enrich the results. I propose three avenues for further inquiry. First, "regional", "peripheral", and many "established" galleries are mainly described here by their distance from the top of the auction market. Better indicators may be found by studying the careers of the artists they propose, by gathering information about the sales they actually achieve, and by studying their local networks of partners (artists, carriers, critics, patrons, etc.) and of buyers and collectors. Second, a better understanding of the social role of providing symbolic goods to cultural elites could be gleaned from systematic data about gallerists: their social background, their careers, their other activities in and outside the art world, and so forth. Third, buyers are only known through a handful of big collectors and patrons-the noble part of art buying -while the art business is far larger than their market share. The importance of the auction market, and its concentration inside national boundaries, is likely the result of a growing demand for decorative goods from hotels, restaurants, malls, official halls, and company offices. An empirical and systematic investigation of these fields would enrich our knowledge of the Indian art world and its place in the sociology of Indian elites.

\section{Appendix 1. Geometrical data analysis of the social space of artists auctioned by Saffronart}

The subsample includes 954 artists who were auctioned by Saffronart at least once. The factorial space is built from 6 active variables with 23 categories.

\begin{tabular}{|l|l|l|}
\hline Active variables & Categories & Numbers \\
\hline \multirow{4}{*}{ Higher bid's level at Saffronart } & one & 608 \\
\cline { 2 - 3 } & two & 134 \\
\cline { 2 - 3 } & three & 90 \\
\cline { 2 - 3 } & four & 65 \\
\hline \multirow{5}{*}{ Born } & five & 57 \\
\hline & 19 th C. & 14 \\
\hline & $1900-45$ & 172 \\
\hline & $1960 s$ & 436 \\
\hline & $1970 s$ & 269 \\
\cline { 2 - 3 } & & \multirow{2}{*}{190} \\
\hline
\end{tabular}




\begin{tabular}{|c|c|c|}
\hline & $1980 \mathrm{~s}$ & 57 \\
\hline & NA & 6 \\
\hline \multirow{2}{*}{ IAF 2008-13 } & no & 529 \\
\hline & yes & 425 \\
\hline \multirow{2}{*}{ Khoj activities } & no & 873 \\
\hline & yes & 81 \\
\hline \multirow{4}{*}{ Canon } & Experimental & 70 \\
\hline & Abstract & 63 \\
\hline & Modern & 122 \\
\hline & no & 699 \\
\hline \multirow{4}{*}{ Most frequent link with galleries } & Representation & 243 \\
\hline & stock & 545 \\
\hline & Exhibition & 153 \\
\hline & Promise & 13 \\
\hline
\end{tabular}

The Multiple Components Analysis (MCA) results in 17 axes (or factors). Axes 1 and 2 explain $26 \%$ of the whole inertia: $15.5 \%$ for axis 1 , and $10.4 \%$ for axis 2 (the next axes explain less than $7 \%$ each).

The first axis is correlated with economic and artistic value indicators: auction bids, attendance at fairs, kind of link with galleries, attendance at Khoj activities. This axis opposes artists with high value (high prices, legitimized by fairs and Khoj, recognition assured through canons), for whom galleries take long-term risks (representation link), against artists with low value and less involving links with galleries (promise, exhibition, less often stock). Members of the "abstract" canon are correlated with higher values, as "auction stars" (all price categories are located on the same side of the axis, other value indicators on the other side).

The second axis is correlated with temporal indicators: birth period, membership in an aesthetic canon. On one side, the oldest artists included in the "modern" canon, and less often in the "abstract" canon. On the other side, the youngest artists pertaining to the "experimental" canon. The artists absent from the three canons are at the middle of the axis, without any correlation with other categories. Concerning kinds of relationships with galleries, representation and exhibition of still-active artists are opposed against stocks and promises of works from dead or less active artists. 


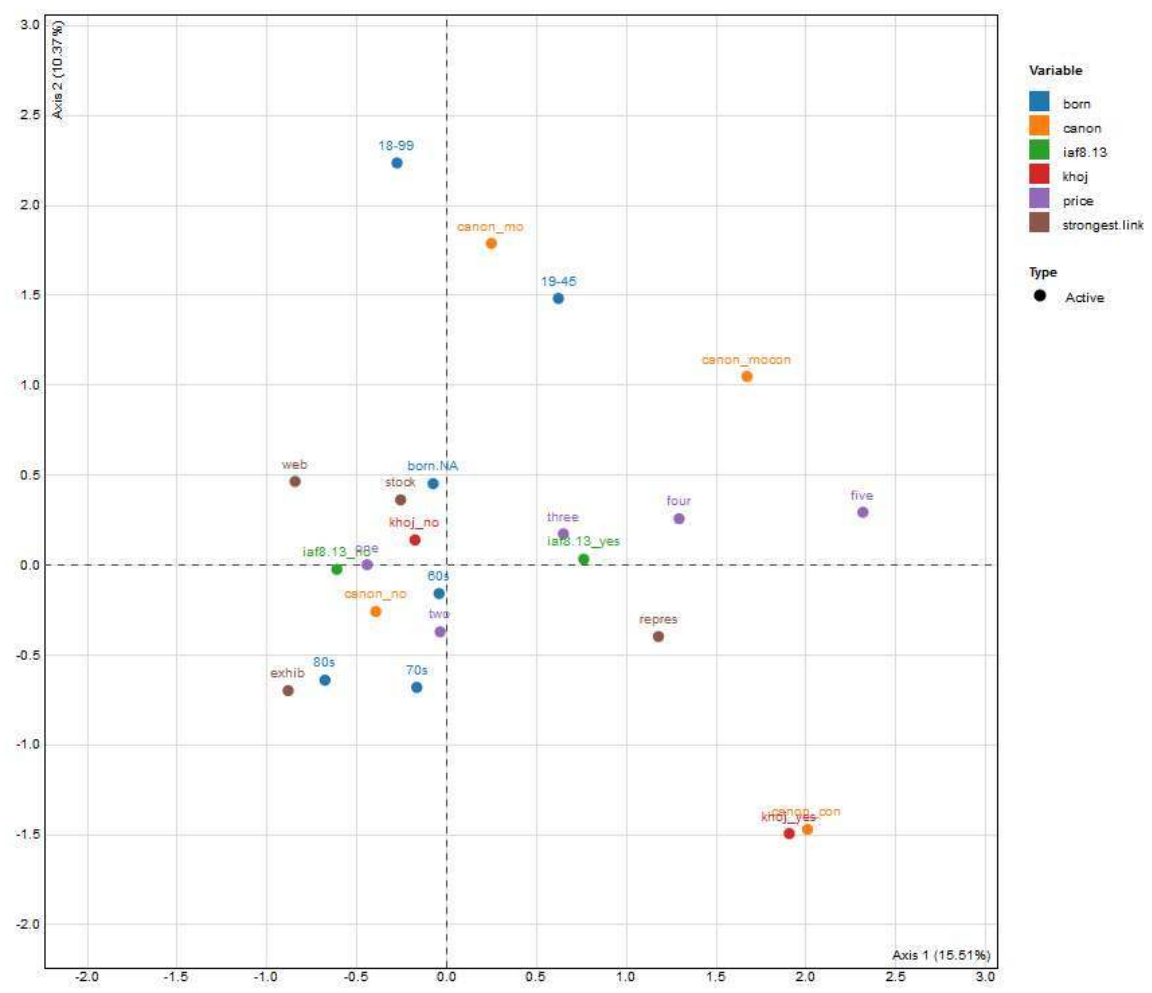

\section{Art Gallery,
Gallery...}


HCA clusters and active variables of the ACM

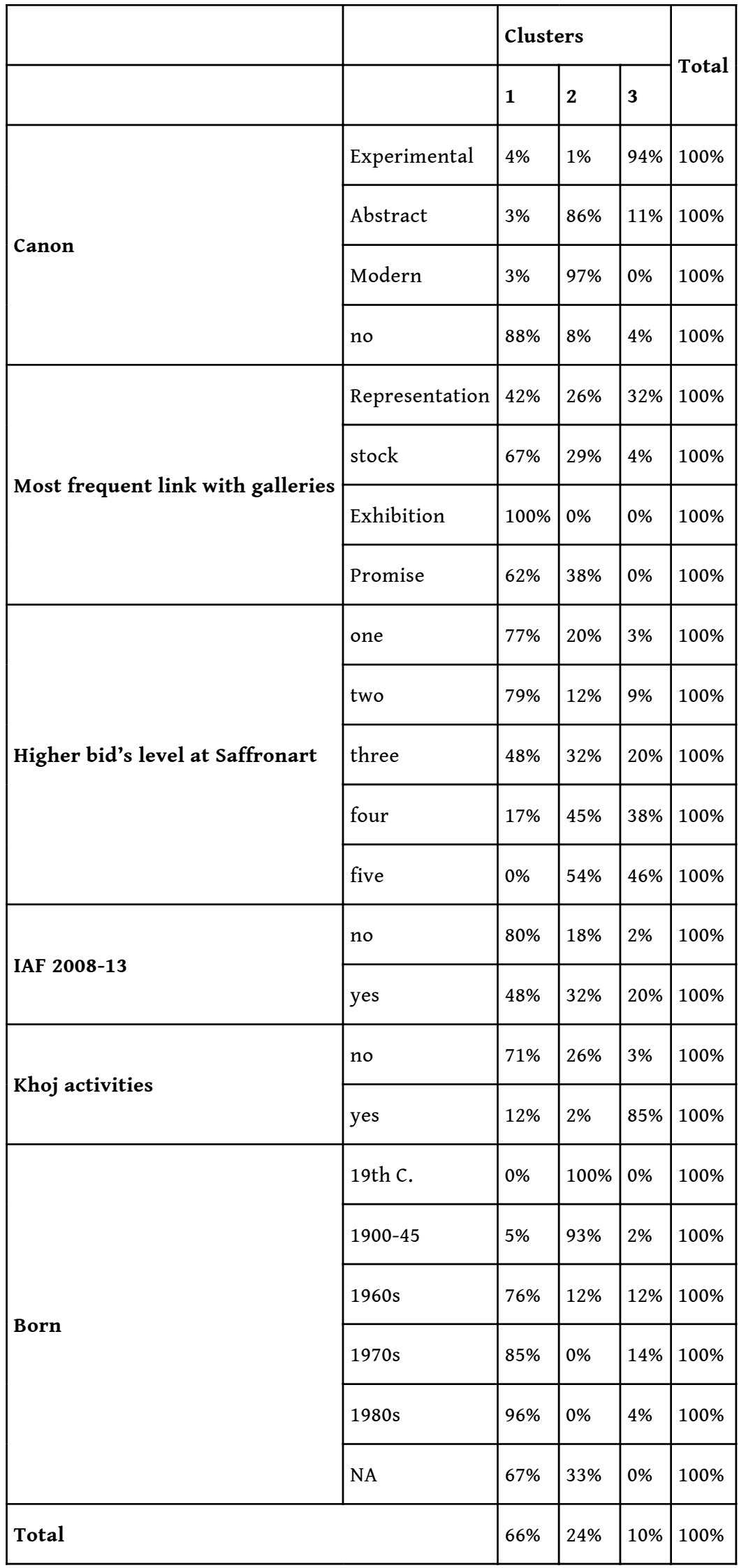


With $66 \%$ of the sub-sample, cluster 1 contains $88 \%$ of artists without reputation (yet already auctioned at least once by Saffronart). These are also the most often exhibited artists-and not stored or represented. They are over-represented among the least valued categories: low auctions, no fairs or Khoj activities. Finally, they are among the youngest, with $96 \%$ under $34,85 \%$ under 44 , and $76 \%$ under 54 . If some of them are still in a position to be valorized in the future, many have already reached a career stage in which it has become unlikely.

With a quarter of the sub-sample, cluster 2 includes almost all recognized artists considered "modern" and $86 \%$ of recognized artists considered "abstract." They tend to receive the highest bids (they represent half of the two highest classes of price), which probably explains their over-representation among the "promise" type of relationship with galleries-and less often the "stock" type. They are potentially lucrative artists on the market, attracting both galleries able to build up stocks and those trying to seduce buyers with promises of access to highly-rated works. For the same reason, they represent almost all artists born before 1945, they are over-represented in fairs, where they provide a classical base for galleries, and they rarely attend "experimental" Khoj activities.

With $10 \%$ of the sub-sample, cluster 3 encompasses almost all the artists of the "experimental" canon. Again, the strongly over-represented properties are consistent. These artists represent $85 \%$ of the artists associated with Khoj, and they are often presented at fairs, although relatively less than the more established artists. They allow the galleries to promote their ability to discover and promote new talents. They are also almost all related to their galleries by "representation" relationships specific to emerging careers as well as to "experimental" networks and aesthetics. Finally, they are more often born in the 1960s and 1970s rather than in the 1980s. Most young artists have not had time yet to access the "experimental" canon (which is defined by the presentation at a minimum of one of the 15 exhibitions on "Contemporary Indian Art" in foreign capitals between 1998 and 2011)-they are thus part of cluster 1.

Most artists are linked to several galleries, especially those who have already been auctioned. That is why no gallery is exclusively associated with a specific cluster. All catalogs include artists from the three clusters; only the proportions vary and sometimes they are not decisive. With such a weak result, the simplest criterion is sufficient to propose an indicative distribution of galleries. The membership of galleries is thus deduced from the most represented cluster among its artists (even when two clusters show few differences). Like any statistical classification, and therefore even more here, the distribution includes a lot of outliers.

Cluster 1: Aakriti Art Gallery, Abadi Art Space, Apparao Galleries, Art Alive Gallery, Art Elements, Art Konsult, Artland, Arushi Arts, Ashish Balram Nagpal Galleries, Body Tree Monastery of Art, Chaithanya Art Gallery, Chawla Art Gallery, Colors Corridor, Creativity Art Gallery, Crimson Art Gallery, Cymroza Art Gallery, Exhibit 320, Focus Art Gallery, Forum Art Gallery, Galleria, Gallery Art Positive, Gallery Beyond, Gallery G, Gallery Kolkata, Gallery Ragini, Gallery Sri Parvati, Gallery Sumukha, Ganges Art Gallery, Genesis Art Gallery, International Creative Art Centre, Kamalnayan Bajaj Art Gallery, Kolkata Art House, Kynkyny, Mahua, Masters Collection Art Gallery, Mirage Art Gallery, MK Search Art, Mon Art Gallery, Polka Art Gallery, Prakrit Art Gallery, Renaissance Art Gallery, Sarala's Art Centre, Studio 3, Studio Palazzo, Tasveer Gallery, The Arts Trust, The Faraway 
Tree, The Stainless Gallery, The Viewing Room, Verandah Art Gallery, Vernissage Gallery, Vinnyasa Premier Art Gallery, Wonderwall.

Cluster 2: Akar Prakar, Amrita Jhaveri Projects, Art Heritage Gallery, Art Indus, Art Musings, Center of International Modern Art, Delhi Art Gallery, Dhoomimal Art Centre, Dhoomimal Gallery, Emami Chisel Art, Gallery 7, Galerie 88, Gallery Alternatives, Gallery Art and Soul, Gallery Art Motif, Gallery Espace, Gallerie Nvya, Gallery Threshold, Gallery Time \& Space, Idiyas Gallery, Janus Art Gallery, Kumar Gallery, Nitanjali Art Gallery, Photoink, Pundole Art Gallery, Tao Art Gallery, Vadhera Art Gallery, Visions Art.

Cluster 3: Chatterjee \& Lal, Chemould Prescott Road Gallery, Crayon Capital Art, Experimenter, Galerie Mirchandani + Steinruecke, Gallery Maskara, GallerySKE, Kashi Art Gallery, Lakeeren, Latitude 28, Nature Morte, Palette Art Gallery, Project 88, Sakshi Gallery, Seven Art Limited, Shrine Empire Gallery, Talwar Gallery, The Guild, The Loft at Lower Parel, Volte.

\section{Appendix 2. More or less shared catalogs: a partition by degrees}

This network partition is the simplest. It is based on the degrees of network vertices, divided into quartiles. In other words, a score is calculated based on the number of galleries with which each gallery shares at least one artist. The resulting distribution of galleries is divided into four classes of equal size. ${ }^{30}$ The information is basic: some galleries have a relatively exclusive catalog, others a relatively shared catalog. With such crude criteria, some resulting groupings are surprising. But the logic of the distribution is still revealing.

\begin{tabular}{|l|l|l|}
\hline \multicolumn{1}{|l|}{ Degrees - 1st quartile } & Over-representation of \\
\hline \multirow{4}{*}{} & Director's sex & male \\
\cline { 2 - 3 } & Main link with artists & representation \\
\cline { 2 - 3 } & City & Mumbai / Delhi \\
\cline { 2 - 3 } & Access & street \\
\cline { 2 - 3 } & Creation & after 2000 \\
\cline { 2 - 3 } & Indian Art Fair 2008-2013 & low \& high \\
\hline \multirow{5}{*}{ Artists } & No auction & very high \\
\cline { 2 - 3 } & Higher bids & low \\
\cline { 2 - 3 } & Khoj activities & low \\
\cline { 2 - 3 } & Modern canon & low \\
\cline { 2 - 3 } & Abstract canon & \\
\cline { 2 - 3 } & & low \\
\cline { 2 - 3 } & &
\end{tabular}


Abadi Art Space; Ashish Balram Nagpal Galleries; Body Tree Monastery of Art; Chatterjee \& Lal; Chemould Prescott Road Gallery; Colors Corridor; Exhibit 320; Experimenter; Galerie Mirchandani + Steinruecke; Gallery G; Gallery Maskara; GallerySKE; Kamalnayan Bajaj Art Gallery; Kolkata Art House; Lakeeren; Mirage Art Gallery; MK Search Art; Nature Morte; Photoink; Project 88; Seven Art Limited; Studio Palazzo; Talwar Gallery; Tasveer Gallery; The Stainless Gallery; Vernissage Gallery; Volte; Wonderwall.

The first quartile consists of the most exclusive catalogs. It includes some isolated peripheral galleries and some galleries dedicated to international experimental art and, more specifically, to the promotion of innovative artists who are not, or not yet, on the auction market. Thus, these last galleries are relatively new, often located in the art districts of New Delhi (Hauz Khas Village and Lado Sarai) or Mumbai (Colaba and Kala Ghoda), and they prefer strong and lasting relationships with a small number of artists that they represent exclusively. These artists have rarely been (already) auctioned, have often taken part in Khoj activities, and are among the most often incorporated into the experimental canon (i.e. presented in foreign exhibitions of contemporary Indian art). Attendance at the India Art Fair is itself divided between the few peripheral galleries that do not have access to financial and curricular resources to be invited and/or pay fees, and the galleries that are already recognized by their peers-these galleries define the cluster's characteristics and have the highest degrees. In sum, sharing few artists with other galleries means either the margins of the Indian art world, or an artistic strategy based on representation and a lesser presence on the Indian auction market.

\begin{tabular}{|l|l|l|}
\hline \multicolumn{1}{|l|}{ Degrees - 2nd quartile } & Over-representation of \\
\hline \multirow{5}{*}{} & Director's sex & female \\
\cline { 2 - 3 } & Main link with artists & exhibition \\
\cline { 2 - 3 } & City & Chennai/Bengaluru/Kochi \\
\cline { 2 - 3 } & Access & all except street \\
\cline { 2 - 3 } & Creation & nineties / after 2008 \\
\cline { 2 - 3 } & Indian Art Fair 2008-2013 & mid \\
\hline \multirow{5}{*}{ Artists } & No auction & high \\
\cline { 2 - 3 } & Higher bids & mid \\
\cline { 2 - 3 } & Khoj activities & low \\
\cline { 2 - 3 } & Modern canon & high \\
\cline { 2 - 3 } & Abstract canon & mid \\
\cline { 2 - 3 } & & \\
\cline { 2 - 3 } & &
\end{tabular}




\begin{tabular}{|c|c|}
\hline Experimental canon & low \\
\hline
\end{tabular}

AKAR PRAKAR; AMRITA JHAVERI PROJECTS; ART INDUS; ARTLAND; CHAITHANYA ART GALLERY; CREATIVITY ART GALLERY; DHOOMIMAL GALLERY; FOCUS ART GALLERY; GALLERY RAgINI; GALLERY SRI PARVATI; IDIYAS GALLERY; INTERNATIONAL CREATIVE ART CENTRE; JANUS ART GALLERY; KYNKYNY; MAHUA; NITANJALI ART GALLERY; SHRINE EMPIRE GALLERY; TAO ART GALLERY; THE FARAWAY TREE; THE GUILD; THE LOFT AT LOWER PAREL; VADEHRA ART GALLERY; VERANDAH ART GALLERY; VINNYASA PREMIER ART GALLERY.

The second quartile mainly includes small and new or established regional galleries. Their main activity is to exhibit artists with little reach, whose aesthetics are relatively accessible (especially modern or the most assimilated part of the abstract canon), and among whom only the stars of regional styles have access to auctions. Apart from these prevailing regional galleries, some significantly different galleries are located at the top of the quartile-Vadehra Art Gallery, The Loft at Lower Parel or Shrine Empire Gallery, for example. These galleries are actually central, present on the auction market through highly rated artists and visible through the promotion of the experimental artists they represent-this mix of highly and little shared artists is probably the reason why they are located here, and not in higher levels of degrees.

\begin{tabular}{|c|c|c|}
\hline \multicolumn{2}{|c|}{ Degrees - 3rd quartile } & \multirow{2}{*}{$\begin{array}{l}\text { Over-representation of } \\
\text { male }\end{array}$} \\
\hline \multirow{6}{*}{ Galleries } & Director's sex & \\
\hline & Main link with artists & stock / exhibition \\
\hline & City & Bengaluru/Kolkata/Kochi \\
\hline & Access & mall / street \\
\hline & Creation & before 1980 / nineties \\
\hline & Indian Art Fair 2008-2013 & high \\
\hline \multirow{6}{*}{ Artists } & No auction & low \\
\hline & Higher bids & high \\
\hline & Khoj activities & low \\
\hline & Modern canon & very high \\
\hline & Abstract canon & high \\
\hline & Experimental canon & mid \\
\hline
\end{tabular}

ART ELEMENTS; ART HERITAgE GALLERY; ART KONSULT; ART MUSINgS; CHAWLA ART GALLERY; CRAYON CAPITAL ART; CRIMSON ART GALLERY; DELHI ART GALLERY; DHOOMIMAL ART CENTRE; EMAMI CHISEL ART; FORUM ART GALLERY; GALERIE 88; GALLERIA; GALLERY ART AND SOUL; GALLERY TIME \& SPACE; GANgES ART GALLERY; GENESIS ART GALLERY; KASHI ART GALLERY; KUMAR GALLERY; MASTERS COLleCtion ART GALleRY; PRAKRIT ART GALLERY; PUNDOLE ART GALLERY; RENAISSANCE ART GALLERY; SAKSHI GALLERY; VISIONS ART. 

the central auction market and thus share significantly more artists with other galleries. They are more established-the oldest galleries are included here-and, in addition to organizing exhibitions, they have an important stock of works. They are also often present at the India Art Fair as their artists are well listed at Saffronart, but they are rarely involved in Khoj experimental activities. Finally, their artists mostly feature in the modern canon, although some fall within the categories of abstract and experimental. Their recruitment pool seems to be made up of all works circulating with good ratings on the market. Most galleries appearing here have been central galleries of the market for several decades, or are more recent galleries whose primary business is to deal a large stock of works at auctions: they have in common the same kind of shared (and well-sold) stocks.

The over-represented cities are "regional" (as opposed to Mumbai and Delhi) but, compared to those over-represented in the second quartile, Kolkata and Chennai replace Bengaluru and Kochi. Kochi is a peripheral city but its three galleries have benefited from the very "experimental" Kochi-Muziris Biennale which has been organized since 2012 (two editions at the time of data collection). Bengaluru is meanwhile the rising city of Indian art, with a relatively small number of galleries (eight) but some of which are well considered and integrated into national and international circuits, mostly "experimental." Chennai appears then as peripheral: its nine galleries are mid-sized (four of them belong to the second quartile). Kolkata, as a former political and cultural capital, is home to 17 galleries represented on all profiles (and thus slightly over-represented in the third quartile). They rarely run artists on the circuits of national and international experimental art but some of their artists belong to central aesthetic schools in the history of Indian art. Defined as "regional", they are nevertheless part of the national pantheon. This small geographical differentiation may explain the differences between the second and third quartiles. They are perhaps not only galleries of the same profile at different stages of integration within the central market, but also galleries benefiting from regional traditions that are themselves more or less present on the central market.

\begin{tabular}{|l|l|l|}
\hline \multicolumn{1}{|l|}{ Degrees - 4th quartile } & Over-representation of \\
\hline \multirow{4}{*}{} & Director's sex & female \\
\cline { 2 - 3 } & Main link with artists & stock / exhibition \\
\cline { 2 - 3 } & City & Delhi \\
\cline { 2 - 3 } & Access & gated / mall \\
\cline { 2 - 3 } & Creation & nineties / 2000s \\
\cline { 2 - 3 } & Indian Art Fair 2008-2013 & very high \\
\hline \multirow{4}{*}{ Artists } & No auction & mid \\
\cline { 2 - 3 } & Higher bids & high \\
\cline { 2 - 3 } & Khoj activities & mid \\
\cline { 2 - 3 } & &
\end{tabular}




\begin{tabular}{|l|l|}
\hline Modern canon & mid \\
\hline Abstract canon & high \\
\hline Experimental canon & low \\
\hline
\end{tabular}

AAKRITI ART GALLERY; APPARAO GALLERIES; ART ALIVE GALLERY; ARUSHI ARTS; CENTER OF INTERNATIONAL MODERN ART; CYMROZA ART GALLERY; GALLERIE NVYA; GALLERY 7; GALLERY ALTERNATIVES; GALLERY ART MOTIF; GALLERY ART POSITIVE; GALLERY BEYOND; GALLERY ESPACE; GALLERY KOLKATA; GALLERY SUMUKHA; GALLERY THRESHOLD; LATITUDE 28; MON ART GALLERY; PALETTE ART GALLERY; POLKA ART GALLERY; SARALA'S ART CENTRE; STUDIO 3; THE ARTS TRUST; THE VIEWINg ROOM.

The fourth quartile mainly includes the central galleries of the auction market-whose summit is occupied by artists belonging to the abstract canon. These galleries are relatively recent and concentrated in New Delhi, nearly all present at the India Art Fairs, and they combine the storage of highly rated works and the exhibition of young, aspiring artists-hence the relatively high rate of absence at auctions and of artists contributing to Khoj activities, and their rare inclusion in the experimental canon. Here we find a kind of statistical basis for the usual opposition between New Delhi, seen as the capital of the established market, and Mumbai, considered the capital of experimental and international contemporary art.

The main interest of this partition by degrees is to make the relative independence of artistic reputation and price level on the auction market apparent. That independence should be understood more as a temporal distance between artistic fame and price increase than as a causal independence. Degrees reflect galleries' positions vis-à-vis artists' auction value: some artists are renowned and highly priced (fourth quartile), some artists are mainly auction products, more or less renowned and "regional" (second and third quartile ${ }^{31}$ ), some artists are either peripheral or young, aspiring artists seeking "experimental" artistic reputation and, maybe in the future, high prices (first quartile).

\section{BIBLIOGRAPHY}

Sources are marked with $\mathrm{a}^{*}$

Accominotti, Fabien. 2008. "Marché et hiérarchie: La structure sociale des décisions de production dans un marché culturel." Histoire \& Mesure 13(2): 177-218.

Artprice. 2011. “Contemporary Indian art.” Retrieved June 12, 2016 (http://www.artprice.com/ artmarketinsight/716/Contemporary+Indian+art).

Becker, Howard S. 1986. “La distribution de l'art moderne." Pp. 433-36 in Sociologie de l'art, edited by R. Moulin. Paris: La Documentation Française.

Benhamou, Françoise, Nathalie Moureau and Dominique Sagot-Duvauroux. 2001. Les Galeries d'art contemporain en France: Portrait et enjeux dans un marché mondialisé. Paris: La Documentation Française. 
Borja, Simon and Séverine Sofio. 2009. "Productions artistiques et logiques économiques: Quand l'art entre en régime entrepreneurial." Regards Sociologiques 37-38: 23-43.

Bourdieu, Pierre. 1971. “Le marché des biens symboliques.” L'Année Sociologique 29: 49-126.

Bourdieu, Pierre. 1979. La Distinction: Critique sociale du jugement. Paris: Minuit.

Byrnstyn, Marcia. 1978. “Art Galleries as Gatekeepers: The Case of the Abstract Expressionists.” Social Research 45(2): 390-408.

*Cousseau, Henry-Claude, Deepak Ananth and Jany Lauga, eds. 2005. Indian Summer: La jeune scène artistique indienne. Paris: ENSBA.

Crane, Diana. 1987. The Transformation of the Avant-garde. The New York Art World, 1940-1985. Chicago, London: The University of Chicago Press.

Crane, Diana. 2016. "La géographie du marché de l'art mondial en pleine évolution : cultures des arts régionales et mondialisation culturelle.” Sociologie et Sociétés 47(2): 19-38.

*Duplaix, Sophie and Fabrice Bousteau, eds. 2011. Paris-Delhi-Bombay. Paris: Editions du Centre Pompidou.

Fernandes, Leela. 2000. "Restructuring the New Middle Class in Liberalizing India." Comparative Studies of South Asia, Africa and the Middle East 20(1): 88-104.

*Fibicher, Bernhard and Suman Gopinath, eds. 2007. Horn Please. Narratives in Contemporary Indian Art. Bern: Hatje Cantz / Kunstmuseum Bern.

Finney, Henry C. 1993. "Mediating Claims to Artistry: Social Stratification in a Local Arts Community." Sociological Forum 8(3): 403-31.

Heinich, Nathalie and Michael Pollak. 1989. "Du conservateur de musée à l'auteur d'expositions: L'invention d'une position singulière." Sociologie du travail 31(1): 29-49.

Hirsch, Paul M. 1972. "Processing Fads and Fashions: An Organization-Set Analysis of Cultural Industry Systems." American Journal of Sociology 77(4): 639-59.

*Holborn, Mark, ed. 2009. The Empire Strikes Back. Indian Art Today. London: Saatchi Gallery / Jonathan Cape.

Ithurbide, Christine. 2010. "Le marché de l'art contemporain en Inde: Enjeux de la mondialisation de l'art contemporain dans les pays émergents." Géographie et Cultures 75: 207-28.

Ithurbide, Christine. 2012. "Marché de l'art contemporain indien: Territoires et réseaux en construction.” Transcontinentales 12-13. Retrieved September 12, 2014 (http:// transcontinentales.revues.org/1347).

Jaffrelot, Christophe and Peter van der Veer, eds. 2008. Patterns of Middle Class Consumption in India and China. New Delhi: Sage.

Jeanpierre, Laurent and Olivier Roueff, eds. 2014. La Culture et ses intermédiaires dans les arts, les industries créatives et le numérique. Paris: Editions des Archives Contemporaines.

Jeanpierre, Laurent and Séverine Sofio. 2015. “Chronique d'une 'mort' différée: Les conservateurs de musée face aux commissaires d'exposition dans l'art contemporain français." Pp. 111-39 in Les conservateurs de musées: Atouts et faiblesses d'une profession, edited by F. Poulard, and J.-M. Tobelem. Paris: La Documentation Française.

Jyrämä, Annukka and Anne Äyväri. 2010. “Marketing Contemporary Visual Art.” Marketing Intelligence \& Planning 28(6): 723-35. 
Kapur, Geeta. 2000. When Was Modernism? Essays on Contemporary Cultural Practice in India. New Delhi: Tulika Books.

Karttunen, Sari. 2008. “Entering the Global Art World: Galleries as Mentors of Peripheral Artists.” Nordisk Kulturpolitisk Tidskrift 11(2): 41-73.

Khaire, Mukti and R. Daniel Wadhwani. 2010. "Changing Landscape: The Construction of Meaning and Value in a New Market Category: Modern Indian Art." Academy of Management Journal 53(6): 1281-304.

Lizé, Wenceslas, Delphine Naudier and Olivier Roueff. 2011. Intermédiaires du travail artistique: A la frontière de l'art et du commerce. Paris: La Documentation Française.

Mitter, Partha. 2007. The Triumph of Modernism: India's Artists and the Avant-garde 1922-1947. London: Reaktion Books.

Moulin, Raymonde. 1967. Le marché de la peinture en France. Paris: Minuit.

Moulin, Raymonde. 1992. L'artiste, l'institution et le marché. Paris: Flammarion.

Moulin, Raymonde. 2000. Le marché de l'art: mondialisation et nouvelles technologies. Paris: Flammarion.

Moureau, Nathalie and Dominique Sagot-Duvauroux. 2012. "Four Business Models in Contemporary Art." International Journal of Arts Management 14(3): 44-56.

*Namin, Kim, ed. 2009. Chalo! India: A New Era of Indian art. Seoul: National Museum of Contemporary Art.

*Neutres, Jérôme, ed. 2007. New Delhi, New Wave. Bologna: Damiani.

Peterson, Karin. 1997. "The Distribution and Dynamics of Uncertainty in Art Galleries: A Case Study of New Dealerships in the Parisian Art Market, 1985-1990.” Poetics 25(4): 241-63.

*Peyton-Jones, Julia, Hans-Ulrich Obrist, Gunnar B. Kvaran, Giulia Ferracci, eds. 2011. Indian Highway. Roma: MAXXI.

*Pusa, Erja, Sointu Fritze, Tuija Kuutti and Jyotindra Jain, eds. 2006. India Express. Sacred and Popular. Helsinki: Helsinki City Art Museum.

Quemin, Alain. 2013. Les stars de l'art contemporain: Notoriété et consécration artistiques dans les arts visuels. Paris: Editions du CNRS.

Rouet, François. 2013. Les galleries d'art contemporain en France en 2012. Paris: DEPS du Ministère de la Culture.

Roux, Sébastien. 2006. "La FIAC ou l'art de vendre: Une institution entre commerce et culture." Pp. 131-56 in Droits d'entrée. Modalités et conditions d'accès aux univers artistiques, edited by G. Mauger. Paris: Les Éditions de la M.S.H.

*Sambrani, Chaitanya, ed. 2005. Edge of Desire: Recent Art in India. London: Philip Wilson Publishers and Palgrave Macmillan.

*Sambrani, Chaitanya, ed. 2007. Hungry God: Indian Contemporary Art. Beijing: Arario / Seoul: Busan Museum of Modern Art.

*Seid, Betty, ed. 2007. New Narratives: Contemporary Art from India. Chicago: Chicago Cultural Center / Ahmedabad: Mapin Publishing.

Sheth, Pratima. 2006. Dictionnary of Indian Art \& Artists. Ahmedabad: Mapin Publishing.

Sinha, Gayatri, ed. 2009. Art and Visual Culture in India, 1857-2007. Ahmedabad: Marg Publications. 
Sofio, Séverine. 2014. "Des stratèges de l'exposition? Le rôle des intermédiaires du marché de l'art dans l'accès des artistes à la notoriété, du $18^{\mathrm{e}}$ siècle à aujourd'hui." Pp. 129-45 in Les stratèges de la notoriété: Intermédiaires et consécration dans les univers artistiques, edited by W. Lizé, D. Naudier, and S. Sofio. Paris: Éditions des Archives Contemporaines.

Sooudi, Olga Kanzaki. 2012. “Art Patron as ‘Taste Scapegoat'? Complicity and Disavowal in Mumbai's Contemporary Art World.” Etnofoor 24(2): 123-43.

Sooudi, Olga Kanzaki. 2015. "Morality and Exchange in the Mumbai Contemporary Art World." Pp. 264-84 in Cosmopolitan Canvases: The Globalization of Markets for Contemporary Art, edited by O. Velthuis, and S. Baia Curioni. Oxford, New York: Oxford University Press.

Srabjee, Deepika. 2011. “Why Indian Galleries are Planting Firm Roots at Art Fairs?” Take On Art 2 (1): 118-21.

*Tatehata, Akira, ed. 1998. Private Mythology. Contemporary Art from India. Tokyo: Japan Foundation Art Center.

Thakurta, Tapati-Guha. 2006. Art, Archeology and the Museums in India: Monuments, Objects, Histories. Institutions of Art in Colonial and Post-Colonial India. New York: Columbia University Press.

*Vajpeyi, Ashok, Sanjay Kumar V, Pedro Tseng and Chieh Lin Maple Yu, eds. 2010. Finding India: Art for the New Century. Taipei: Museum of Contemporary Art Taipei.

Velthuis, Olav. 2005. Talking Prices: Symbolic Meanings of Prices on the Market for Contemporary Art. Princeton, NJ: Princeton University Press.

Velthuis, Olav, and Stefano Baia Curioni, eds. 2015. Cosmopolitan Canvases: The Globalization of Markets for Contemporary Art. Oxford and New York: Oxford University Press.

Verlaine, Julie. 2013. Les galeries d'art contemporain à Paris de la Libération à la fin des années 1960: Une histoire culturelle du marché de l'art, 1944-1970. Paris: Publications de la Sorbonne.

Vermeylen, Filip. 2015. "The India Art Fair and the Market for Visual Arts in the Global South." Pp. 31-52 in Cosmopolitan Canvases: The Globalization of Markets for Contemporary Art, edited by O. Velthuis, and S. Baia Curioni. Oxford and New York: Oxford University Press.

*Wiehager, Renate, ed. 2007. Private / Corporate IV: Works from the Lekha and Anupam Poddar, and Daimler Chrysler Collections: A Dialogue. Berlin: Daimler Art Collection / New Delhi: Devi Art Foundation.

*Yashodara, Dalmia. 2001. The Making of Modern Indian Art: The Progressives. New Delhi: Oxford University Press.

Yogev, Tamar and Thomas Grund. 2012. "Network Dynamics and Market Structure: The Case of Art Fairs." Sociological Focus 45(1): 23-40.

\section{NOTES}

1. This study was possible thanks to Christine Ithurbide, Jules Naudet, and the welcome of the staff and director, Leilla Choukroune, of The Centre for Social Sciences and Humanities in New Delhi. It was funded by the National Institute for Social and Human Sciences (French National Center for Scientific Research) and by Université de Vincennes Saint-Denis (Paris 8). I also thank the anonymous reviewers and Alexis Pernsteiner for their useful comments and advice.

2. Appendices present two other methods for partitioning the galleries' networks and their results. 
3. For contemporary art, I rely mainly on Ithurbide (2010; 2012).

4. Art departments at Jawaharlal Nehru University and Delhi University, Kala Bhavan in Santiniketan, Maharaja Sayajirao University in Baroda, Sir JJ School of Arts in Mumbai.

5. It would be interesting to study the impact of artistic requests for humanitarian operations, whether state or non-governmental. Workshops and exhibitions are frequent and sometimes offer artists occasional income and/or value signals for resumes.

6. As a foreign outsider, I repeatedly heard during interviews, conversations, or even during the presentation of my inquiry at a conference, that "there is Husain and Husain" (or other stars' names)-that is, certain "common," "decorative," "vulgar" works are intended for public galleries and auctions, and other "valuable," "unique" works are intended for "friends" (i.e. members of elite interpersonal networks). Another "secret" concerns the production of avatars, a way of profiting from the previous "secret": when a work sells "well" (i.e. at a high price, and to a famous collector), the artist produces several similar works (neither copies nor series, which lead to lower prices; the same with small differences), either by anticipation or at the request of some buyers.

7. A list of the artists (as well as the exhibition archive) can be found here: http:// www.aaa.org.hk/Collection/CollectionOnline/SpecialCollectionItem/3853

8. The figure is probably overstated due to the lower representation of Indian companies in the Artprice database.

9. According to Srabjee (2011): in 2006, Nature Morte and Bose Pacia participated in Art Basel; in 2008, GallerySKE in Frieze; in 2009, Project 88 in Frieze ("Section Frame"); in 2010, Experimenter in Frieze ("Section Frame"); the same year, at Art Basel, Nature Morte and Bose Pacia were in the "Main Section," Chemould Prescott Road and Sakshi Gallery in the "Art Features" section, Chatterjee \& Lal and GallerySKE in the "Art Statements" section. If still rarely, their artists are increasingly reported by foreign galleries-the first is probably Subodh Gupta, via Pierre Huber (Geneva), at The Armory Show in 2002, in 2005 in Frieze, in 2006 in Art Basel.

10. Informative interviews were also conducted with six central and peripheral gallerists in Delhi.

11. Ahmedabad, Hyderabad, and Pune were first included, but their galleries were never part of the multiple lists consulted in later phases. The final sample therefore reflects the "Indian art world" as merely seen from its core (or its national "summit"), and fails to represent completely the country's numerous "regional" artistic networks.

12. I thank the staff of the Foundation for Indian Contemporary Art's Reading Room at Vadhera Art Gallery Bookstore in Delhi as well as Peter Nagy and the staff of the gallery Nature Morte for their welcome and assistance.

13. One hundred and one galleries may seem like a small number considering the size of the Indian population (1.25 billion in 2011), and compared, for example, to the 2,191 contemporary art galleries in France (for a population of 66 million) (Rouet 2013). But the true population of reference is probably also quite low. In India, the market for modern and contemporary art is far smaller than the market for decorative visual arts, crafts, antiques, and traditional handicrafts.

14. Exclusivity is mostly limited to a territory (India, a city), sometimes to a period (at least several years), sometimes to a sample of an artist's works (monumental works excluded, agreement for direct sales, etc.).

15. Sometimes, storage does not imply the purchase of works: the risk is then to dedicate part of the stockroom (and all implied expenditures) to them.

16. If it does not use its name, the gallery takes no reputational risk: there is no commitment to the artist.

17. The gallery is then paid through a commission on the sale.

18. One gallery is run by two male partners; they are counted as one "male." 
19. The author has been collecting information since 1993, contacting about 2,000 artists either directly or through a questionnaire. Her selection was based on exhibitions: at least five individual shows and several collective shows "in reputed art galleries," except for artists who were active before the development of galleries, and for young artists who have not yet had time for five individual shows.

20. See bibliography.

21. The size of the sample made the collection of data on foreign galleries impossible. Foreign galleries represent an important variable for peripheral markets (Karttunen 2008). But the association between the "experimental" canon and internationalization is assumed here based on other studies (Vermeylen 2015; Velthuis and Baia Curioni 2015) and interviews.

22. The following table does not include the relationship between galleries and artists. It is possible to characterize each gallery unequivocally based on the highest degree of risk even if several types of relationships are invested (as is often the case). This is not possible for artists who have different relationships in various galleries since the distribution is not linear. That variable will be included in network analyses, since they focus on the 9,879 links between 1 artist and 1 gallery.

23. Classes are calculated based on the Fisher-Jenks algorithm (function "classIntervals" in Robert Bivand's package "classInt" for R software): given a predefined number of classes, it finds the smallest intra-class variance, and the biggest inter-classes variance. The highest price is $115,125,001$ rupees.

24. These measures, uninformative aside from the fact that they establish the existence of a structured and therefore sociologically relevant network, are available from the author.

25. Function equiv.clust of package sna for R software.

26. Function blockmodel of the same package sna for $\mathrm{R}$.

27. In the sense of removing part of the statistical "noise" in favor of network prominent properties.

28. The ACM was realized with the package explor for R.

29. The classification tree shows a gap between 3 and 4 clusters.

30. Quartile, albeit crude, proved sufficient: smaller quantile or partition by k-means (minimizing the distance of each point belonging to a class from the average score for this class) do not provide additional information. With an odd number of galleries (101), and several galleries located on the maximum value of the first quartile, the classes are actually unequal: they include 28 galleries for the first quartile and 24, 25, and 24 galleries for the subsequent quartiles.

31. My hypothesis is that these two quartiles represent the large market of "decorative" works for hotels, restaurants, offices, official halls, and so forth.

\section{ABSTRACTS}

In recent years, researchers have expressed renewed interest in the visual arts, which can be seen as one of the main providers of upper-class symbolic goods and status signals for cultural elites. India has not yet been included in that body of work. Although important insights do exist on India, a systematic empirical inquiry has yet to be made. The present article offers a step in that direction, through the statistical analysis of 101 Indian galleries and the 4,249 artists they 
present in their catalogs. Does the way galleries share artists reveal specific characteristics about the Indian art world? Is the usual opposition between "commercial" and "artistic" galleries relevant for contemporary India? What are the roles of auctions and international fairs? Do Indian galleries prefer representing artists, or storing and exhibiting their works? What insights do their strategies and hierarchies offer about the cultural standards of Indian elites? This article offers a typology of Indian art galleries based on a network analysis (blockmodeling). It reveals a hierarchized system, the weight of the auction market, and a strong economic and aesthetic boundary between international experimental art and national modern art.

\section{INDEX}

Keywords: art galleries, network analysis, cultural intermediaries, Indian art world, art fairs and art auctions

\section{AUTHOR}

\section{OLIVIER ROUEFF}

Research Fellow in sociology at the CRESPPA-CSU (French National Center for Scientific Research) 